\title{
Rancang Bangun Shaking Water Bath Berbasis Mikrokontroler ATmega16
}

\author{
Khairiati Husni*, Wildian, Meqorry Yusfi \\ Jurusan Fisika, Universitas Andalas \\ Laboratorium Elekstronika dan Instrumentasi, Jurusan Fisika, Universitas Andalas, Padang \\ *khairiatihusni@gmail.com
}

\begin{abstract}
ABSTRAK
Shaking water bath berbasis mikrokontroler ATmega16 telah dirancang-bangun. Shaking water bath terdiri dari alat shaking dan water bath. Water bath digunakan untuk memanaskan sampel dalam air pada suatu temperatur konstan. Air dipanaskan oleh elemen pemanas dan temperaturnya diindera oleh sensor temperatur LM35. Temperatur air dipertahankan sesuai dengan rentang yang diinginkan. Elemen pemanas dikendalikan dalam modus on-off dengan menghidup-matikan relai. Alat shaking water bath menggunakan motor mesin cuci $220 \mathrm{~V}$ untuk menguncang-guncang (shaking). Laju motor diatur secara manual dengan sebuah potensiometer pada rangkaian pengendali. Nilai temperatur air dan lama waktu pemanasan yang diinginkan dimasukan melalui keypad dan ditampilkan pada LCD. Uji akhir alat memperlihatkan bahwa alat ini mampu mengendalikan temperatur air yang diinginkan dalam lebarrentang (span) optimal sebesar $10^{\circ} \mathrm{C}$. Alat mampu beroperasi paling lama sekitar 30 menit sebelum motor mengalami kelebihan panas yang menyebabkan putarannya melambat.

Kata kunci: shaking water bath, modus on-off, LM35, mikrokontroler
\end{abstract}

\section{ABSTRACT}

A shaking water bath based on microcontroller ATmegal6 has been designed. Shaking water bath consists of shaking and water bath. The water bath is used to incubate samples in water at a constant temperature. The water is warmed by a heating elements, and its temperature is detected by an LM35 temperature sensor. The temperature is maintaned in a desired range value. The heating element is controlled in an on-off mode by turning a relay. The shaking water bath uses a washing machine motor of $220 \mathrm{~V}$ for shaking. The motor speed is adjusted manually with a potentiometer in a control circuit. The value of the water temperature and the duration of heating are input through a keypad and displayed on an LCD. The final test showed that this equipment can control the water temperature in the range of $10^{\circ} \mathrm{C}$. The equipment can operate all about 30 minutes before the motor overheated causing its rotation become slower.

Keywords: shaking water bath, on-off mode, LM35, microcontroller

\section{PENDAHULUAN}

Shaking water bath merupakan suatu alat yang digunakan untuk keperluan laboratorium dan industri, seperti pencampuran zat kimia, pembentukan suatu organisme baru bahkan digunakan untuk pencairan dan inkubasi sampel darah. Salah satu contoh penggunaan alat shaking water bath dalam skala laboratorium yaitu untuk menganalisis bahan pakan ternak di laboratorium peternakan. Shaking water bath memiliki dua buah sistem yaitu shaking dan water bath. Alat shaking water bath ini dapat mempertahankan temperatur serta laju putaran motor pada kondisi tertentu. Sistem shaking yang bekerja pada alat ini menggunakan sebuah motor untuk mengaduk sampel dan sistem water bath menggunakan suatu sensor temperatur untuk memepertahankan temperatur yang diinginkan.

Alat shaking water bath tidak banyak diproduksi di Indonesia, sehingga untuk keperluan laboratorium di Indonesia alat shaking water bath dibeli ke luar negeri (Jerman, Amerika dan China) dengan harga yang mahal yaitu Rp. 30.000 .000 (Thermoscientific, 2014). Harga yang mahal ini mengakibatkan ketersediaan alat di beberapa laboratorium Indonesia sangat minim. Ketersediaan alat yang minim mengakibatkan penggunaan alat dipaksakan sehingga sering mengalami kerusakan pada bagian motor.

Akibat mahalnya harga shaking water bath, beberapa peneliti mengembangkan alat shaking water bath berharga murah di antaranya Kurniawati (2006) merancang bangun alat water bath menggunakan mikrokontroller AT89C51. Penelitian ini hanya mengontrol temperatur pada alat water bath dan alat yang dirancang tidak memiliki shaking. Penelitian lainnya dilakukan oleh Dwinata (2008) yaitu rancang bangun progammable shaking untuk 
water bath. Penelitian ini bertujuan untuk mengatur laju pada motor DC menggunakan Pulse Width Modulation (PWM), sedangkan untuk kontrol temperatur dan waktu belum dilakukan. Penelitian lain dilakukan oleh Mandayatma (2009) yaitu water bath menggunakan kontrol logika fuzzy, penelitian ini hanya mengontrol waktu dan temperatur dan tidak memiliki shaking. Kekurangan penelitan ini adalah sedikitnya variasi untuk waktu dan temperatur $\left(30^{\circ} \mathrm{C}-40^{\circ} \mathrm{C}\right)$. Khairani (2015) mengembangkan alat solution shaking menggunakan motor stepper. Hasil penelitiannya dapat memutar beban seberat $400 \mathrm{~g}$. Kelemahan dari alat ini nilai laju putaran motor sangat lambat $(12,02 \mathrm{~cm} / \mathrm{s})$ untuk putaran tanpa beban.

Berdasarkan dari penelitian yang telah dilakukan serta untuk mengatasi kekurangankekurangan penelitian sebelumnya, maka dalam tugas akhir ini dibuat rancang bangun alat shaking water bath dengan harga murah dan dapat mengontrol temperatur, waktu dan laju putaran motor. Rancangan alat ini dibuat menggunakan motor AC yang dilengkapi dengan sensor temperatur dan elemen pemanas air. Penelitian ini juga dapat melihat beban maksimum yang dapat diputar oleh alat agar motor yang digunakan tidak cepat rusak.

\section{METODE}

\subsection{Bahan dan Alat}

Bahan dan alat yang digunakan dalam perancangan ini yaitu LM35, mikrokontroler ATmega16, LCD $2 \times 16$, elemen pemanas air, motor induksi satu fasa (motor mesin cuci pengering $220 \mathrm{~V}$ ), multimeter, termometer, Personal Computer (PC), relai dan keypad. LM35 digunakan sebagai pendeteksi temperatur, ATmega16 digunakan untuk memproses keluaran sensor, LCD 2 x 16 digunakan sebagai penampil nilai temperatur. Motor mesin cuci digunakan untuk alat shaker, multimeter digunakan sebagai alat ukur tegangan dan relai untuk sistem kontrol on-off, termometer digunakan untuk alat ukur temperatur

\subsection{Perancangan Diagram Blok Sistem}

Dalam perancangan alat shaker water bath dibutuhkan beberapa rangkaian blok sistem seperti diperlihatkan pada Gambar 1. Masing-masing perancangan blok sistem terdiri dari rangkaian sensor temperatur, dua sistem keypad, dua sistem minimum mikrokontroler, dua rangkaian relai, kontrol kecepatan motor dan dua LCD.

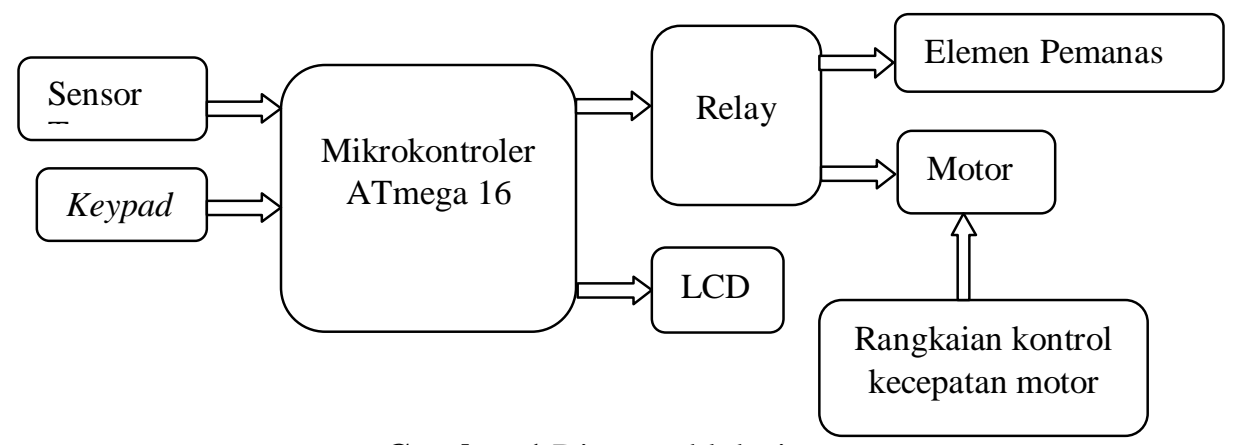

Gambar 1 Diagram blok sistem

\subsection{Perancangan Rangkaian Keseluruhan}

Perancangan rangkaian sistem secara keseluruhan dapat dilihat pada Gambar 2. Perancangan sistem secara keseluruhan terdiri dari sistem minimum mikrokontroler, LCD, sistem sensor LM35, sistem keypad, sistem relai, dan sistem pengaturan laju motor. Untuk sistem minimum mikrokontroller, relai, LCD dan keypad masing-masing ada dua sistem dan rangkaiannya sama dengan Gambar 2. 


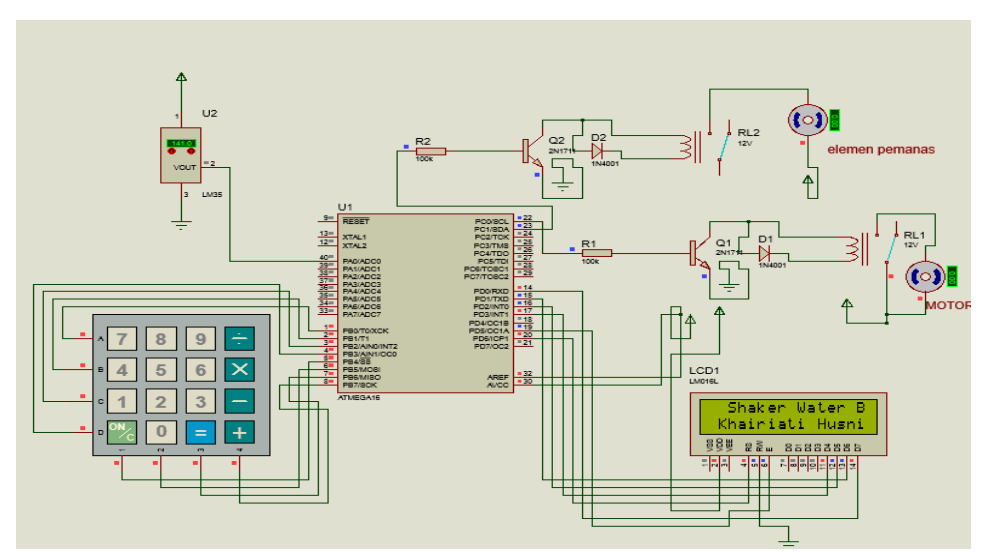

Gambar 2 Skematik rangkaian keseluruhan

\subsection{Perancangan Perangkat Lunak Sistem}

Bentuk perancangan diagram alir sistem dapat dilihat pada Gambar 3. Temperatur dan waktu penggunaan alat yang diinginkan dimasukan melalui keypad. Keluaran dari keypad akan diproses oleh mikrokontroler. Sistem akan hidup ketika tombol start pada keypad ditekan dan sensor LM35 akan mendeteksi nilai temperatur air. Apabila masukan temperatur lebih kecil dari temperatur awal, maka elemen pemanas air aktif dan memanaskan air, jika temperatur yang dideteksi lebih besar dari temperatur air yang diinginkan, maka elemen pemanas mati. Apabila temperatur yang dideteksi oleh LM35 sudah sama dengan masukan yang diinginkan, maka proses pemanasan akan berhenti. Jika belum, elemen pemanas akan terus melakukan proses pemanasan. Selama alat digunakan, nilai temperatur dan lama penggunaan alat akan ditampilkan di LCD. Apabila tampilan di LCD tidak sesuai dengan masukkan pada keypad, maka proses akan berulang dari logika pertama, namun jika tampilan masukan waktu sudah sama dengan lama penggunaan alat maka alat akan berhenti.

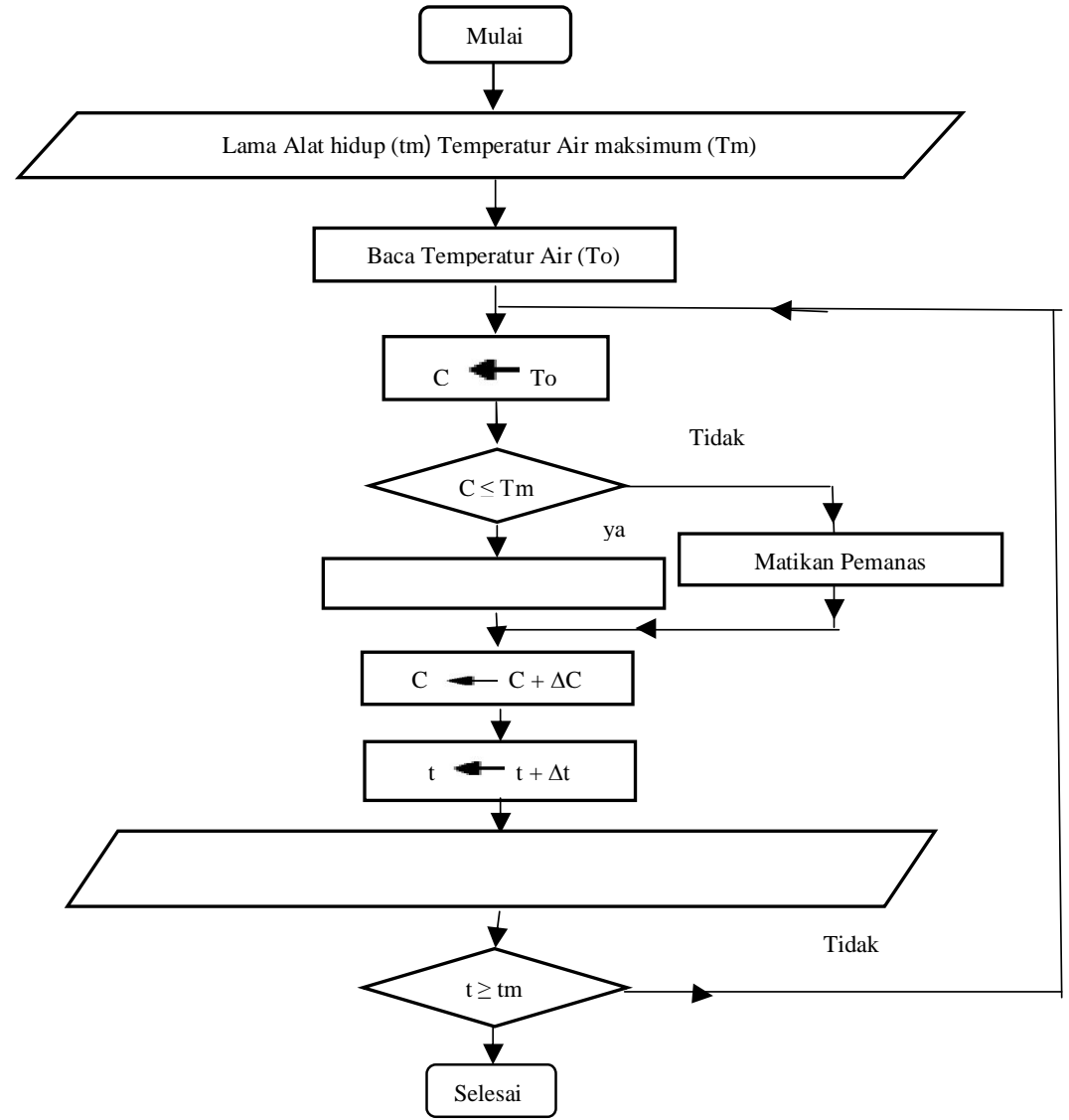

Gambar 3 Diagram alir sistem 


\subsection{Perancangan Bentuk Fisik Alat}

Gambar 4 menunjukkan bentuk fisik alat secara keseluruhan. Bak air dirancang dengan volume $225 \mathrm{~m}^{3}$ dengan panjang $50 \mathrm{~cm}$, lebar $30 \mathrm{~cm}$ dan tinggi $15 \mathrm{~cm}$. Bentuk ukuran dari bak air yang dirancang sesuai dengan kapasitas untuk memuat 4 buah tabung erlenmeyer. Elemen pemanas, sensor LM35 dan tabung erlenmeyer yang berisikan sampel dimasukan kedalam air. Motor dan sistem rangkaian elektronika diletakkan pada suatu tempat di luar bak air. Hal ini bertujuan untuk memudahkan dalam mengoperasikan sistem pengontrolan.

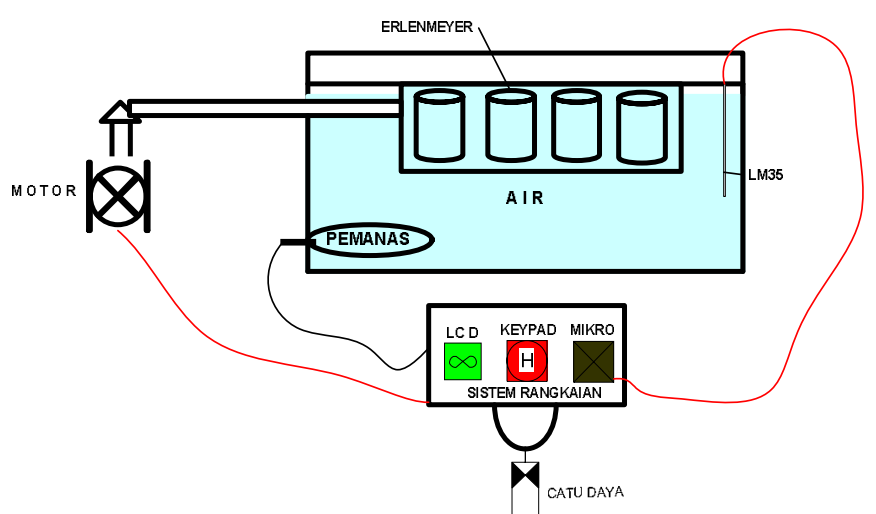

Gambar 4 Perancangan bentuk fisik alat

\section{HASIL DAN DISKUSI}

\subsection{Hasil Rancangan Shaking Water Bath}

Shaking water bath yang telah dibuat dapat dilihat pada Gambar 5. Biaya yang diperlukan untuk membuat alat shaking water bath ini adalah sekitar Rp. 1.000.000,00. Alat shaking water bath terdiri dari rangkaian sistem minimum mikrokontroller, LM35, rangkaian pengatur laju motor, relai, catu daya, LCD, keypad, elemen pemanas dan tabung erlenmeyer.

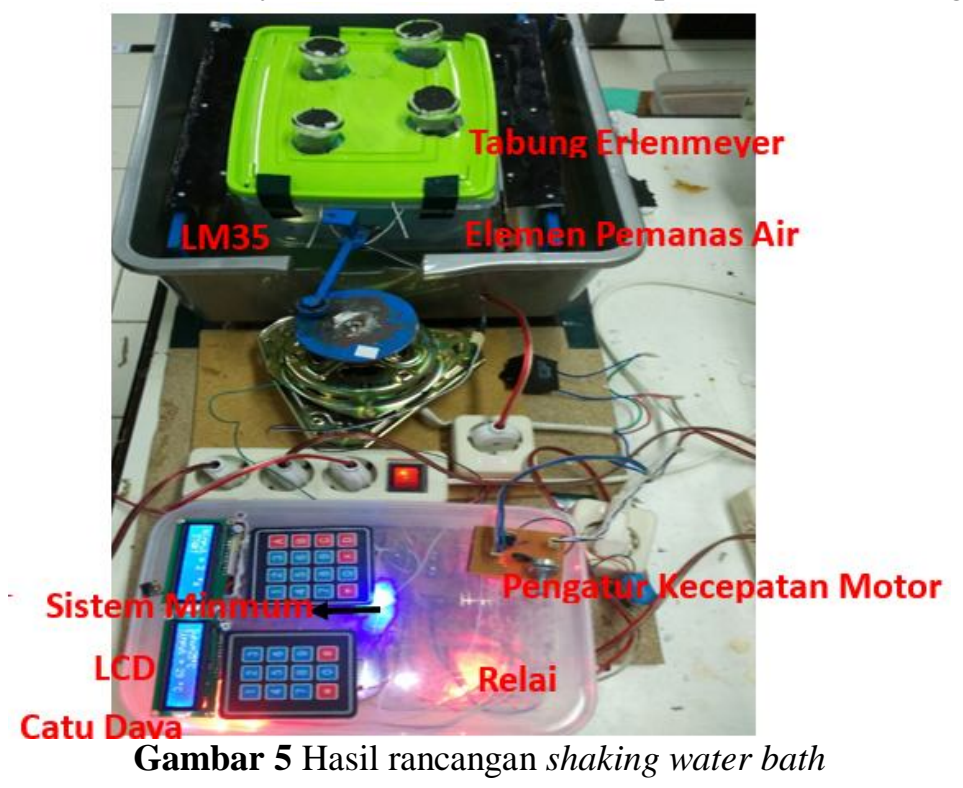

\subsection{Hasil Pengujian Sensor Temperatur LM35}

Data temperatur yang diuji pada pengujian sensor LM35 berkisar antara $20{ }^{\circ} \mathrm{C}-90{ }^{\circ} \mathrm{C}$. Hal ini karena dalam penggunaan alat shaking water bath dibutuhkan temperatur antara $20^{\circ} \mathrm{C}-$ $90{ }^{\circ} \mathrm{C}$. Hasil pengujian sensor LM35 berupa perbandingan antara nilai temperatur dengan nilai tegangan keluaran dapat dilihat pada Gambar 6. 


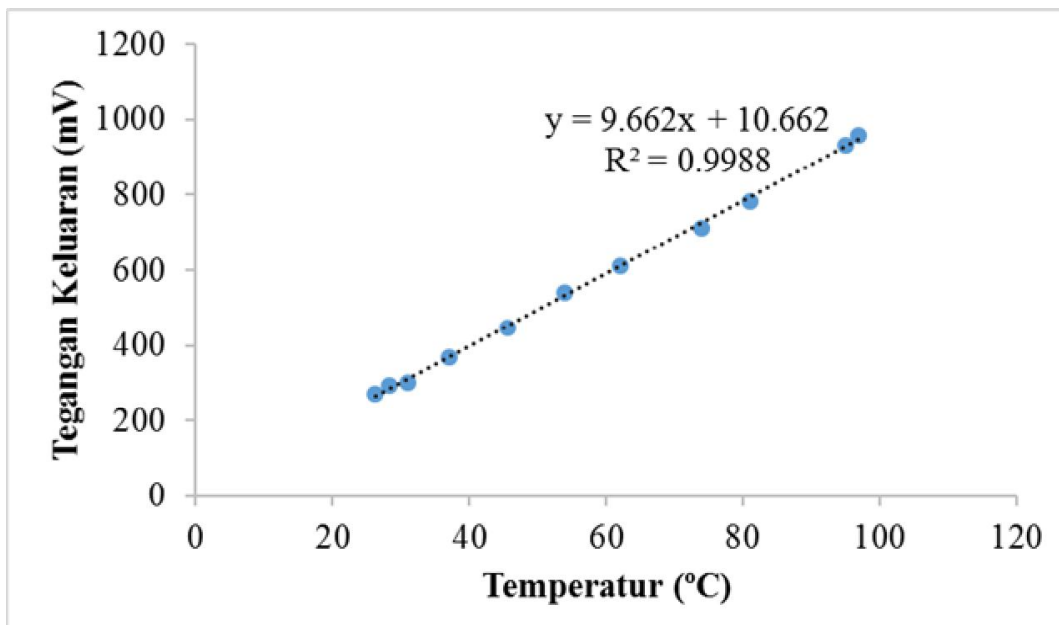

Gambar 6 Hasil pengujian sensor temperatur LM35

Pada Gambar 6 didapatkan fungsi transfer dari hasil perbandingan antara tegangan keluaran dengan nilai temperatur yaitu $y=9,662 x+10,662$. Fungsi transfer ini menunjukan bahwa setiap perubahan temperatur sebesar $1,0^{\circ} \mathrm{C}$ menghasilkan perubahan tegangan keluaran sebesar 9,662 mV dan memiliki nilai tegangan offset sebesar 10,662. Nilai tegangan offset ini merupakan nilai tegangan awal sensor pada saat temperatur bernilai nol adalah 10,662 $\mathrm{mV}$.

Fungsi transfer yang ditunjukkan pada Gambar 6 menghasilkan nilai regresi mendekati 1 yaitu sebesar 0,9988. Nilai regresi ini menunjukkan bahwa tingkat keliniaran sensor sangat baik, sehingga dapat digunakan sebagai alat ukur temperatur. Hasil keluaran sensor yang sudah dikarakterisasi ini sesuai dengan datasheet bahwa tingkat keliniaran LM35 yaitu setiap perubahan nilai temperatur $1^{\circ} \mathrm{C}$ akan menghasilkan nilai tegangan keluaran sebesar $10 \mathrm{mV}$. Hasil keluaran dari sensor temperatur berupa data analog yaitu nilai tegangan. Mikrokontroler harus diprogram untuk menampilkan nilai keluaran sensor dalam bentuk digital. Mikrokontroler akan memproses tegangan keluaran dari sensor yang dimasukan ke Port A. Port A ini memiliki data ADC 10 bit, yang akan mengkonversi data analog berupa tegangan ke data digital berupa nilai temperatur yang akan ditampilkan di LCD.

\subsection{Hasil Pengujian Kontrol Temperatur}

Sistem kontrol temperatur yang digunakan pada penelitian ini adalah sistem kontrol onoff. Pengoperasian sistem kontrol on-off menggunakan rangkaian relai sebagai saklar, sehingga keluaran sistem kontrol on-off hanya dua kondisi yaitu pada saat saklar terbuka maka sistem akan on dan pada saat saklar tertutup sistem akan off. Pada pengujian kontrol temperatur ini data yang diambil yaitu $40{ }^{\circ} \mathrm{C}$ dan $50{ }^{\circ} \mathrm{C}$, hal ini karena untuk menghomogenkan beberapa larutan umumnya dibutuhkan temperatur $40^{\circ} \mathrm{C}$ sampai $50^{\circ} \mathrm{C}$.

(a)
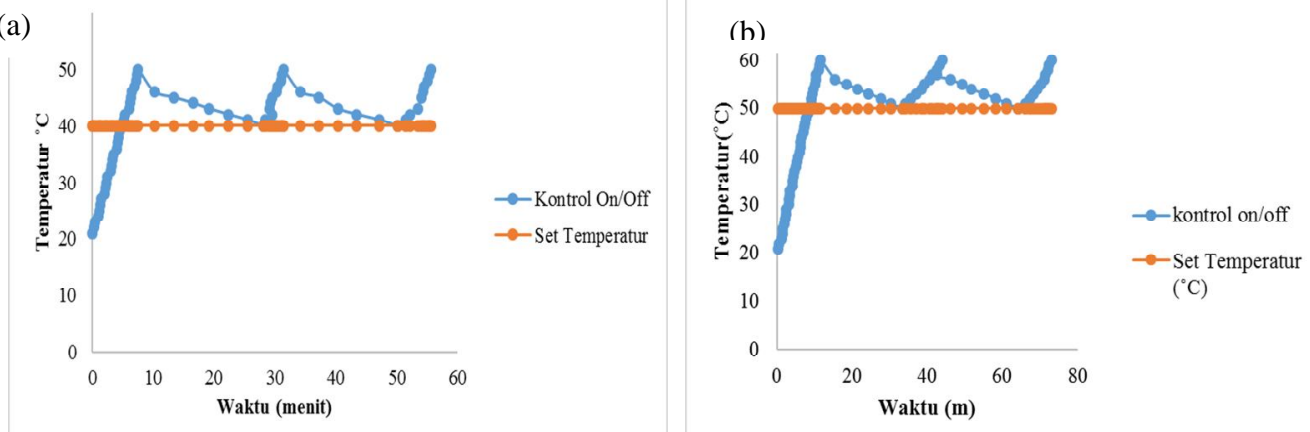

Gambar 7 Hasil pengujian kontrol temperatur (a) $40{ }^{\circ} \mathrm{C}$ (b) $50^{\circ} \mathrm{C}$

Hasil pengujian kontrol temperatur $40{ }^{\circ} \mathrm{C}$ dapat dilihat pada Gambar 7. Berdasarkan Gambar 7 (a) pengaturan temperatur yang dimasukan melalui keypad adalah $40{ }^{\circ} \mathrm{C}$ sebagai temperatur acuan, sedangkan temperatur awal air yang akan dipanaskan adalah $22{ }^{\circ} \mathrm{C}$. Saat 
sistem kontrol dihidupkan maka elemen pemanas air akan aktif dan menaikkan temperatur air sampai $50{ }^{\circ} \mathrm{C}$. Apabila lebih dari $50{ }^{\circ} \mathrm{C}$ maka pemanas akan mati sampai sensor mendeteksi perubahan temperatur sama dengan $40^{\circ} \mathrm{C}$. Pada akhirnya sistem ini akan menjaga kestabilan temperatur antara $40{ }^{\circ} \mathrm{C}-50{ }^{\circ} \mathrm{C}$ selama 20 menit dan untuk pengujian sistem kontrol temperatur $50{ }^{\circ} \mathrm{C}$ dapat dilihat pada Gambar 7 (b). Hasil yang didapatkan untuk proses kontrol temperatur $50{ }^{\circ} \mathrm{C}$ hampir sama dengan pengaturan temperatur $40{ }^{\circ} \mathrm{C}$.

\subsection{Hasil Pengujian Kontrol Waktu}

Pada shaking water bath dibutuhkan pengaturan waktu yang otomatis, sehingga lebih mudah dalam penggunaannya. Pengujian kontrol waktu pada shaking water bath digunakan stopwatch sebagai pembanding antara waktu yang terbaca oleh progam dengan waktu yang sebenarnya. Gambar 8 merupakan hasil dari perbandingan antara waktu yang dimasukan pada alat dengan waktu yang sebenarnya. Perbandingan antara masukan keypad dengan waktu yang sebenarnya adalah linear dengan regresi mendekati nilai 1, namun waktu masukan pada keypad berbeda dengan waktu yang sebenarnya. Saat waktu masukan pada keypad 1 menit, waktu yang tercatat pada stopwatch adalah 1 menit lewat 15 detik. Hal ini juga terjadi pada menit yang lain dimana semakin besar nilai masukan pada keypad maka erorr dari waktu yang sebenarnya semakin besar. Ini terlihat dari nilai masukan 10 menit, dimana perbandingan dengan waktu yang sebenarnya yaitu 12,08 menit. Hal ini karena untuk mengontrol waktu pada alat shaking menggunakan progam dengan bahasa BASCOM, dimana setiap proses yang terjadi pada progam membutuhkan waktu tunda sehingga waktu yang dikontrol tidak sama dengan yang sebenarnya.

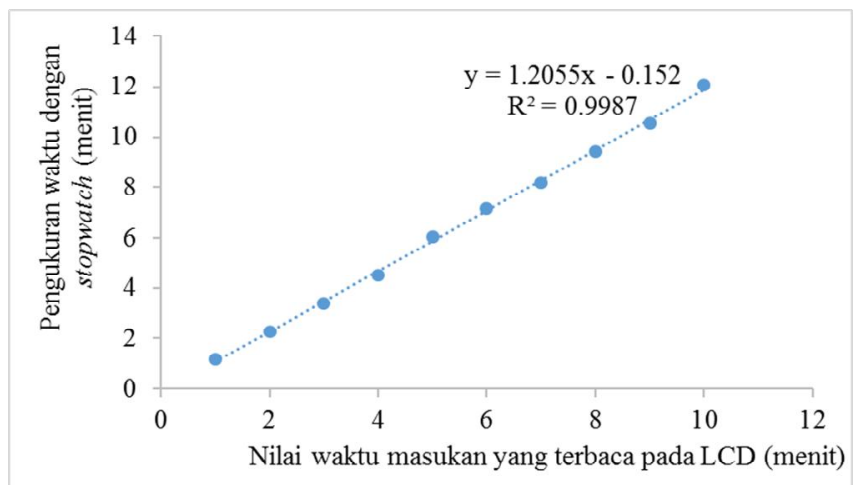

Gambar 8 Hasil pengujian kontrol waktu

\subsection{Hasil Pengujian Rangkaian Pengatur Laju Motor}

Pengujian rangkaian laju putar motor digunakan untuk melihat nilai tegangan keluaran dari rangkaian. Besaran yang dibandingkan dalam pengujian rangkaian pengatur laju motor adalah nilai resistansi dengan nilai tegangan keluaran. Gambar 9 merupakan hasil pengujian rangkaian pengatur laju motor menggunakan komponen triac, diac dan potensiometer. Rangkaian pengatur laju putaran motor ini dapat mengurangi tegangan keluaran pada saat nilai resistansi diubah-ubah pada potensiometer. Perbandingan antara resistansi dan nilai tegangan keluaran adalah berbanding terbalik, semakin besar resistansi yang diputar pada potensiometer, maka nilai tegangan keluaran yang dihasilkan akan semakin kecil. Hal ini karena potensiometer sebagai hambatan akan mengurangi tegangan keluaran pada rangkaian dan tegangan keluaran dari rangkaian ini akan mempengaruhi laju putaran motor. 


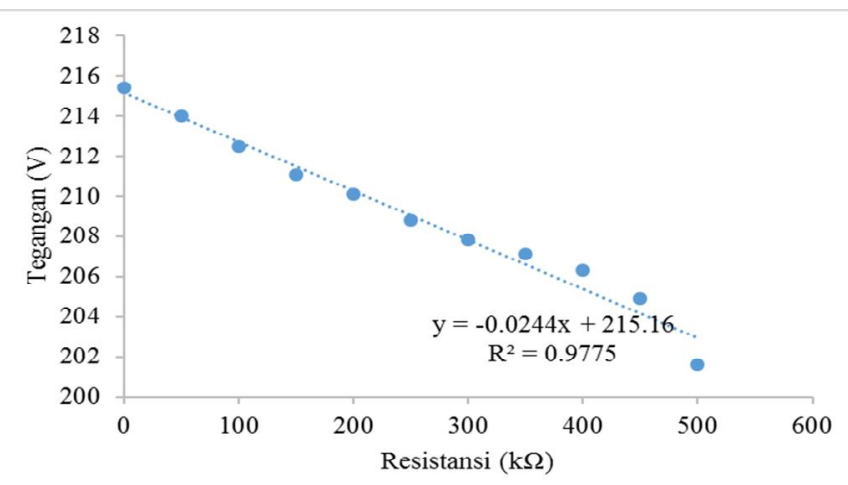

Gambar 9 Hasil pengujian rangakian pengatur laju motor

\subsection{Hasil Pengujian Beban dan Laju Motor}

Hasil pengujian nilai laju putaran motor dengan variasi $420 \mathrm{ml}-1500 \mathrm{ml}$ ditunjukan pada Gambar 10. Dari hasil pengujian dapat dilihat bahwa untuk semua pengaturan berat beban, motor dapat berputar disaat nilai resistansi kecil dari $300 \mathrm{k} \Omega$, namun pada saat nilai resistansi diatas $300 \mathrm{k} \Omega$ motor tidak dapat bergerak. Hasil yang didapatkan dari pengujian beban dan laju putaran motor dapat dilihat bahwa semakin besar berat beban yang diberikan maka resistansi yang diberikan adalah semakin kecil. Hal ini dapat bandingkan antara volume $420 \mathrm{ml}$ dengan volume $1500 \mathrm{ml}$, dimana untuk volume $420 \mathrm{ml}$ pada resistansi $280 \mathrm{k} \Omega$ nilai putaran motor mencapai $138 \mathrm{rpm}$, sedangkan untuk volume $1500 \mathrm{ml}$ pada resistansi yang sama, nilai putaran motor yang didapatkan adalah $65 \mathrm{rpm}$. Hal ini menunjukan bahwa untuk volume $1500 \mathrm{ml}$ membutuhkan tegangan yang besar untuk memutar beban. Beban maksimum yang mampu diguncang oleh alat adalah $1500 \mathrm{ml}$, sedangkan diatas beban $1500 \mathrm{ml}$ alat tidak mampu lagi memutar beban dengan indikasi motor tidak dapat bergerak.

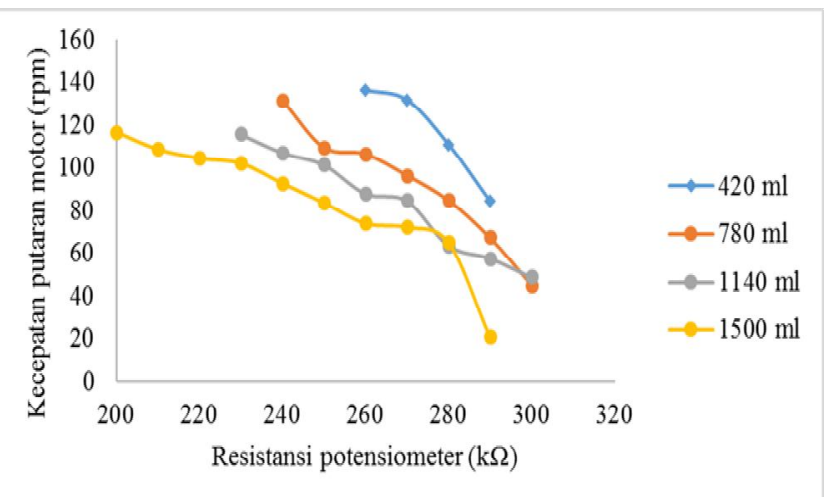

Gambar 10 Grafik hasil pengujian beban dan laju motor

\section{KESIMPULAN}

Pada tugas akhir ini telah berhasil merancang sebuah shaking water bath yang mampu mengontrol temperatur air dalam wadah dan lama waktu kerja alat secara otomatis, serta mengatur laju motor AC secara manual. Sistem kontrol on-off yang digunakan untuk mengontrol temperatur air pada wadah dapat mempertahankan temperatur dalam lebar-rentang $10^{\circ} \mathrm{C}$. Shaking water bath yang dihasilkan ini mampu beroperasi selama 30 menit.

\section{DAFTAR PUSTAKA}

Dwinata, A., 2008, Rancang Bangun Progamable Shaking Untuk Water Bath, Skripsi,Instrumentasi Elektronika dan Industri, UI, Depok.

Khairani, R., 2015, Rancang-Bangun Sistem Kontrol Solution Shaking Berbasis Mikrokontroler AT89S51 dengan Motor Stepper sebagai Penggerak, Jurnal Fisika Unand, Vol.7, No. 1, Jur. Fisika Unand. 
Kurniawati, J., 2006, Rancang bangun Water Bath Menggunakan Mikrokontroller AT89C51, Skripsi, Teknik Elektro, UNEJ, JemberPribadi, S., "Pemodelan Tsunami untuk Peringatan Dini BMG”, (BMKG, Jakarta, 2008), hal 131-147

Mandayatma, E., 2009, Waterbath dengan Kontrol Logika Fuzzy untuk Proses Gnogenesis dalam Upaya Meningkatkan Produksi Benih Ikan Mas (Cyprinus Carpio), Jurnal Seminar Nasional Electrical, Informatics, and It's Education.

Thermoscientific, 2014, Thermo Scientific Laboratory Products. 